\title{
Career/lifelong guidance systems and services: continuous transformations in a transition region
}

\section{The case of three Central and Eastern European Countries}

\author{
T. B. Borbély-Pecze ${ }^{1}\left[\right.$ · L. Hloušková ${ }^{2} \cdot$ T. Šprlák ${ }^{3}$
}

Received: 7 May 2020 / Accepted: 12 March 2021 / Published online: 31 March 2021

(c) The Author(s), under exclusive licence to Springer Nature B.V. 2021

\begin{abstract}
This comparative study traces the foundation and development of vocational and career guidance services in three Central and Eastern European countries in the light of the contextually bound factors of this region. Since the beginning of the 20th century, political transitions and changes in the ruling structures in these countries were so frequent that the same generation was often confronted with multiple forms of governance: the rule of 'König und Kaiser', the monarchy, the communist regime, neoliberal economic policies with mass privatisation, membership of the European Union.
\end{abstract}

Keywords Institutional instability · Central and Eastern Europe $\cdot$ Lifelong guidance policy

\section{Résumé}

Systèmes et services d'orientation professionnelle tout au long de la vie: Transformations continues dans une région en transition Le cas de trois pays d'Europe centrale et orientale Cette étude comparative retrace la fondation et le développement des services d'orientation professionnelle dans trois pays d'Europe centrale et orientale à la lumière des facteurs liés au contexte de cette région. Depuis le début du 20e siècle, les transitions politiques et les changements de structures gouvernemen-

\footnotetext{
T. B. Borbély-Pecze

borsborbely@yahoo.com

L. Hloušková

hlouskov@phil.muni.cz

T. Šprlák

tomas.sprlak@gmail.com

1 John Wesley Theological College, Budapest, Hungary

2 Department of Educational Sciences, Faculty of Arts, Masaryk University, Brno, Czechia

3 CCI Meurthe et Moselle, Nancy, France
} 
tales dans ces pays ont été si fréquents qu'une même génération a souvent été confrontée à de multiples formes de gouvernance : le règne du "König und Kaiser", la monarchie, le régime communiste, les politiques économiques néolibérales avec la privatisation de masse, l'adhésion à l’Union européenne.

\section{Zusammenfassung}

Berufs-/Lebensbegleitende Beratungssysteme und Dienstleistungen: Kontinuierliche Transformationen in einer Transitionsregion Der Fall von drei mittelund osteuropäischen Ländern Diese vergleichende Studie zeichnet den Aufbau und die Entwicklung von Berufs- und Laufbahnberatungsdiensten in drei mittel- und osteuropäischen Ländern vor dem Hintergrund der kontextabhängigen Faktoren dieser Region nach. Seit Beginn des 20. Jahrhunderts waren politische Übergänge und Veränderungen der Herrschaftsstrukturen in diesen Ländern so häufig, dass ein und dieselbe Generation oft mit mehreren Regierungsformen konfrontiert war: die Herrschaft von 'König und Kaiser', die Monarchie, das kommunistische Regime, neoliberale Wirtschaftspolitik mit massiver Privatisierung, die Mitgliedschaft in der Europäischen Union.

\section{Resumen}

Sistemas y servicios de orientación profesional a lo largo de la vida: Transformaciones continuas en una región en transición. El caso de tres países de Europa Central y Oriental El caso de tres países de Europa Central y Oriental Este estudio comparativo muestra la fundación y el desarrollo de los servicios de orientación profesional en tres países de Europa Central y Oriental a la luz de los factores contextuales de esta zona. Desde principios del siglo XX, las transiciones políticas y los cambios en las estructuras de gobierno en estos países fueron tan frecuentes que una misma generación se enfrentó a menudo a múltiples formas de gobierno: el gobierno de "König und Kaiser", la monarquía, el régimen comunista, las políticas económicas neoliberales con privatizaciones masivas y la adhesión a la Unión Europea.

"Those who do not remember the past are condemned to repeat it." (G.

Santayana)

\section{Introduction}

Hungary, the Czech Republic and the Slovak Republic, the Central and Eastern European (CEE) states, are geographically in the heart of the European continent and are members of the European Union (EU) and the Organisation for Economic Co-operation and Development (OECD), but their national career guidance services and systems and regional co-operation in the field of career guidance are barely known outside these countries. Career guidance services across the globe and in Europe have continuously been mapping themselves against developing international and regional voluntarily set or tripartite-dialogue-agreed standards, such as the different conventions of the International Labour Office (ILO, 1975, Convention No. 142), OECD (OECD, 2004a), the European Lifelong Guidance Policy Network (ELGPN, 2015) and 
European Commission (Barnes et al., 2020). The European Commission's Communication "Making a European area of lifelong learning a reality" highlighted key role of guidance in lifelong learning strategies with a strong focus on access to career guidance services for everyone (European Communities, 2001), and this was given political expression in The Council Resolution (Council of the European Union, 2004) on strengthening policies, systems, and practices for lifelong guidance.

Despite their geographical location in the heart of Europe, there has been little analysis of national guidance systems and career guidance services of CEE countries. Some analysis exists (ELGPN, 2012; ETF, 2003; Watts \& Borbély-Pecze, 2011), but it mainly concentrates on the performance of certain sectors such as employment, adult training, vocational education or school counselling. They provide an incomplete picture of the goals and capabilities of the guidance system of these countries. National or international policy recommendations frequently refer to the same weak points without acknowledging the relation between different sectoral policies or elements of the national guidance systems or the contextual factors particular to each country. For example, initial vocational education (I-VET) and the performance of public employment services (PES) are two sides of the same coin, for example, early school leaving in I-VET is often framed as youth unemployment in PES. Career/school counsellors, local PES officers, and others are often staff of local boards dealing with problems of the target groups of career guidance services e.g. early school leavers, the unemployed. Therefore, the real cross-policy nature, value, and performance management of career/ lifelong guidance often remain hidden in these discussions.

Understanding the nature, goals, and capacities of countries' career/ lifelong guidance systems also requires an in-depth knowledge of these countries' cultural heritage, including values and other features, which are bound up with a country's history.

This article is a first joint venture of Slovak, Czech, and Hungarian authors to start building a common platform for the description and understanding of the development of career guidance services of CEE countries. The analysis focuses on the transitions from vocational guidance services to career guidance services since the end of the 19th century, the communist regime and its changes (1989/1991), and more recently from career guidance policy to lifelong guidance policy since EU membership (2004).

While the term vocational guidance refers to one-off directive and remedial activity, the term career guidance denotes preventive and learner-centred processes as key components of services that support labour market transitions, thereby building individuals' patchwork careers (EC, 2011; Watts et al., 2010). The latest version of the OECD skills strategy (OECD, 2019) describes career guidance as a building block of new skill ecosystems in countries.

\section{Developing common ground}

The development of common ground in career guidance is a recent phenomenon for CEE countries. While such cooperation is very far from a Scandinavian type or a Baltic type of co-operation, there are some new positive signs. Regional co-operation started in the last 15 years; the common work of the ELGPN (2007-2015) permitted a comparative overview of the career guidance systems and services of 
CEE countries. Cross-border seminars (CBS) organised by Euroguidance (EG) during the same period have paved the way for a better regional understanding. The work of ELGPN has provided a comprehensive toolbox for the systematic review of national/regional lifelong guidance services (ELGPN, 2012, 2015). Currently, CareersNet, a network of the European Centre for the Development of Vocational Training (CEDEFOP) provides a further opportunity for co-operation at regional level. This network also helps the development of CEDEFOP strategic papers on issues such as investment in career guidance (CEDEFOP, 2019b).

Although many professionals from the CEE countries have been participating in these networks, and in international guidance conferences and discussions since the fall of the Iron Curtain and have been following the international trends, practices and research in the field, they still have not been accumulating professional knowledge by closely looking at their neighbours' developments. This is particularly true for Hungarians and Slovaks, as the distance between the two capital cities is a 2-h car drive; there are also language barriers. For Bratislava, Prague used to be the primary reference point, but for the new generation of guidance professionals, researchers, and policy analysts, English has become the language for regional communication as German was a hundred years ago.

\section{Defining Central Europe: geography and power games}

The economic developments of the last few decades and the open borders of the Schengen Zone as well as the access to different European mobility tools (such as Erasmus+, previously Tempus, etc.) have created a situation whereby both political attention and the focus of daily life and businesses have been moving back to the region. Germany is still the most important trading and political partner, but strategic links between the countries of the region have also emerged. At the macropolitical level, the V4 (Visegrad Four or Visegrad [Vyšehrad or Plintenburg] Group, (established in 1991) is a good example of this shift in interest.

The definitions of who are CEE states are also manifold. The OECD uses the term to refer to the group of countries comprising Albania, Bulgaria, Croatia, the Czech Republic, Hungary, Poland, Romania, the Slovak Republic, Slovenia, and the three Baltic States of Estonia, Latvia, and Lithuania. However, for the purposes of this paper, the three Baltic States, and the Balkan countries (Albania, Bulgaria, Romania) are not included as those countries underwent a partly different historical development. However, Austria, which became a new entity after the collapse of the Monarchy, and re-established itself again in 1955, and since has been referred to as a Central-European country, is mentioned in this analysis. The original name of Austria before the Habsburgs clearly describes its status Ostarrichi (996), means "eastern realm", as an eastern line of defense.

The CEE nations were part of the Habsburg Empire, after the collapse of the Czech Kingdom, from the late 13th century (1274) and were united under the Habsburg Empire once the Ottoman Empire was defeated in the region (Treaty of Karlowitz, 1699). Thus, "Mitteleuropa" (Central Europe) countries have shared and 
experienced a different history from the western part of geographical Europe over a long period of time.

Austria became the only one of the newly established countries capable of moving close to the Western part of Europe as a result of the Austrian Independence Treaty signed by the Occupying Powers in 1955. However, in geographical terms Central Europe is more diverse. Pre-World War I "Mitteleuropa" served the needs of the Habsburg Empire. It mainly lost its economic and power balance after the Prussian-led unification of Germany without the Habsburgs in 1866. The region was always a transition buffer zone between German and Russian interests. In these power games, local Slavic nations were used as buffers or were pitted against each other. The strong influence of the Catholic Church and German as a lingua franca were the common features of the region until the end of World War I. This status quo collapsed with the fall of the Hapsburg Empire, namely the Austro-Hungarian Empire. After the Second World War, the "ferryboat country", as the Hungarian poet Endre Ady (Berend, 1996, p. 380) called Hungary and also the region, moved to the Soviet side, excluding Austria (mentioned above), and Slovenia and Croatia (which became part of Yugoslavia). This status quo changed again after the collapse of the USSR in 1991 and the granting of EU and NATO membership to these countries during the late 1990s and early 2000s.

Szúcs and Parti (1983) described three different development zones of Europe from the Middle Ages: CEE referring to V4 countries (Poland, Hungary, Slovakia, and Czech); Austria, Slovenia, Croatia; and the former territories of the GDR, the German Democratic Republic (Neue Bundesländers after 1990). CEE is a region where rules and rulers, systems, and institutional settings have changed at least four times during the 20th century. The first systems level change occurred at the collapse of the Habsburg Empire (1918) and the establishment of independent states. This was followed by occupations by the Third Reich during the Second World War and by the Soviet Union at the end of the war. Short-lived independence with pluralist democracy existed between 1945 and 1947. Later, there were 40 years of communist regimes with different characteristics in the national states (Czechoslovakia, Hungary, Poland and German Democratic Republic) followed by a change in the political structures again in the 1990s (end of the Soviet Union), to the prototypes of the new parliamentary democracies. In 2004, CEE countries obtained EU membership. The 2008-2009 global crisis effect significantly decreased the support for pluralist democracies in the region. These political-system-level changes were always crossconnected with ideology and welfare regimes. After a "golden decade" (2010-2019) of economic development of the region, in the period of 2016-2018 the average net monthly wages in Euros were 2410 EUR in Germany, 2217 in Austria, 932 EUR in the Czech Republic, 833 EUR in Slovakia, and 701 EUR in Hungary. World Bank (WB) data shows that remittances formed part of gross domestic product (GDP): $2.9 \%$ for Hungary, $2 \%$ for the Slovak Republic, and 1.6\% for the Czech Republic (WB, 2019b). According to the latest World Happiness Report, life evaluations in CEE have shown a continuous and remarkable improvement from 2010 to 2019 (United Nations, 2020, p. 25). However, given all the geopolitical changes, the level of individual/household economic security and of trust in government has never been high in the region. 


\section{Values and uncertainty}

Career guidance services are not only connected with people and their career choices but also with the structure and values of the society and the shape and opportunities of the labour market (ELGPN, 2012; OECD, 2004b). In this respect, the development of the CEE region and the current opportunities in the region are different from the western part of Central Europe.

For example, the brain drain is a major labour market challenge in CEE (European Committee of the Regions, 2018). Not only highly skilled but all types of blue-collar and semi-skilled workers have been continuously migrating, mainly to the German and Austrian labour markets. Living standards are significantly lower in CEE and the employment security (ILO, 2015) of the citizens and families, relevant for career changes and development is significantly weaker than in the western part of Europe. Employment security also affects the values of the society as well as of individuals and provides a relatively unique situation and challenges for career guidance/development policy, system development, and delivering guidance services.

Since 1981, the Global Value Survey results have been describing societal values of different world regions. The evaluation of data is based on a very simple frame of reference, where traditional values are evaluated against secular-rational values, and survival values are rated against self-expression. The CEE region is positioned as a traditional survival world region. This means:

- Traditional values emphasise the importance of religion, parent-child ties, deference to authority, and traditional family values. People who embrace these values also reject divorce, abortion, euthanasia, and suicide. These societies have high levels of national pride and a nationalistic outlook.

- Survival values place emphasis on economic and physical security. It is linked with a relatively ethnocentric outlook and low levels of trust and tolerance (Inglehart \& Welzel, 2015).

The history of vocational/career guidance services in a region is always cross connected with social and economic developments, including the structure and needs of the labour market and the changing mission statement of vocational training and education. The modernisation of the Austro-Hungarian monarchy (as it was called from 1867) started much later than the western part of Europe. The following part of this article provides an overview of three countries' guidance systems, namely Hungary, Slovakia, and the Czech Republic, and demonstrates the different, dashed, and overdue history of the region and its consequences for the development from vocational guidance through career guidance to lifelong guidance systems and services. 


\section{Historical overview: the institutionalisation of vocational and career guidance in the CEE countries}

As the monarchy was largely less industrialised and urbanised than Western Europe, the need for vocational guidance became viable around the third part of the 19th century in response to growing unemployment among workers in industries and the mass inflow of unskilled agricultural workers to towns. The common denominator of institutionalisation of vocational guidance at the turn of the 19th and 20th centuries was the changing views of work-and, hence, also unemployment. Jobs provided not only for the individual (including their family) but were also a kind of goods subject to the laws of supply and demand. Unemployment was therefore not a symptom of individual (ir)responsibility, guilt, or bad mores; it became a mass phenomenon connected with poverty, petty crime, alcoholism, and several other negative social phenomena. The unemployed, and hence the poor, were not only vagabonds, idlers, or people incapable of work, but their numbers were growing by encompassing until-then obedient citizens who had become unemployed due to hard-to-predict economic crises (Rákosník, 2008).

The history of the first big economic crisis of 1873 showed that mass unemployment could not be handled by tools intended to take care of the poor based on charity or in corrective institutions (Rákosník, 2008). Problems experienced by the growing numbers of unemployed as well as young apprentices facing difficulties finding a job were gradually claiming the attention of public care, based in this period on the assumption that the interests of people in a society should be satisfied in ways benefiting the whole (Hlavačka et al., 2015).

Due to the differing contexts, vocational guidance services were developing differently in the so-called Cisleithania (the historical lands of Bohemia, Moravia, and Silesia among those under analysis in this paper) in contrast with the socalled Transleithania, namely in the Hungarian Kingdom (modern-day Hungary and Slovakia).

\section{Transleithania}

The real institutionalisation of vocational guidance services had been started at the turn of the 20th century. It followed the abolition of the guild system in 1872 and the first act on home servants passed in the Hungarian Parliament in 1876. At that time, only one-tenth of the active population was engaged in industry and mining. Food, milling and rail industries were the forerunners of modernisation, and these economic sectors magnetised the new workforce.

It is not by accident that the first institutionalised sign of vocational guidance dates to 1899 when Pál Ranschburg established his first vocational psychological laboratory in Budapest. A few years later, the first law on vocational training/industrial apprenticeship was passed by the Hungarian Parliament (1884, p. XVII). The first vocational guidance institution named the Special Education Laboratory of the Hungarian Kingdom was set up in Budapest by Lipót Szondi in 1906 as vocational training became more relevant to industry and specialised education gained more 
visibility. In Budapest, the vice-mayor opened a city institute for vocational guidance in 1912. The institute was supervised by László Nagy, a pedagogic psychologist.

After the collapse of the Austro-Hungarian monarchy, the first special education institute, called the Education and Vocational Guidance National Institute, was established in 1929, founded by Dr János Schall, a neuropathist. Just as Hungary entered World War II, a new vocational guidance institution was opened in Budapest, chaired by Ferenc Mérei, and it was operational until the Soviet occupation of the country in 1947 (Gebauer, 2017).

\section{Cisleithania}

One of the blanket solutions used by Cisleithanian public administration to address unemployment was the integration of employment services in the legal system. Fundamentals of systematic organisation of public employment offices-established to provide information for free, to mediate between employers and people seeking employment, and advise all who might be seeking a job-were set by Law no. 57/1903, applicable only to Czech nationals (Janák, 1997, p. 101). Before public employment offices were established and in parallel with them, advice was given, and jobs were mediated by associations of traders, alliances, private persons, and, in some cases, municipalities themselves (Janák, 1997).

Other impulses shaping vocational guidance services at the end of the AustroHungarian monarchy can be found in the first counselling centres (e.g. the network of counselling centres for children set up by Adler) and psychological clinics (Pech, 1937).

During the relative rapid modernisation of the monarchy before World War I, Gross National Product (GNP) progress was 1.73\% between 1870 and 1913; during the same period, Britain had 1\%, France $1.06 \%$ and Germany $1.53 \%$ GNP growth per a year. This was still not enough to cover the gap between Western and Central and Eastern Europe (Cipolla, 1973).

At the end of World War I, the state borders of CEE changed drastically. New states and structures were established between 1918 and 1920. Austria and the Hungarian Kingdom were split after a long joint history under the Habsburgs. In the north, newly independent countries, Hungary and Austria, and a new country, Czechoslovakia, were created; in the south, the Kingdom of Serbs, Croats and Slovenes, later known as Yugoslavia, was established. The Habsburg Empire at the heart of Europe was dead.

The German-Austrian roots of significant psychologists were still very important for the new-born or geographically and ethnically reshaped countries. Names such as that of Wilhelm Maximilan Wundt and his individual psychology theories, Alfred Adler, Viktor Frankl, Sigmund Freud, or psychotechnics by Münsterberg had a long heritage in this region as German remained the language of science until the end of World War II. But after 1920, national languages (Czech and Slovak, Hungarian, Serbian, Croatian, Slovenian, Romanian and Austria-German) became the official languages of the new states as well as the languages of science and state-run services, including vocational guidance. 


\section{Czechoslovakia (1918-1993)}

The Czechoslovakia was established in 1918. In the same year, the National Assembly of the Czechoslovak Republic approved the guidelines for establishing guidance centres designed to help children and adults choose appropriate jobs and employment (Rákosník, 2008). Experts started to influence the process of job selection, which had been an exclusively private-run business until then.

The first vocational guidance institution-including an office to find jobs for apprentices-was established by Land's Trade Board of Brno in 1919. In Moravia, guidance institutions were established as a part of district services for the young, and this practice gradually spread to Bohemia as well. A guidance centre was founded in Prague in 1920, which was became part of the Central Psychotechnic Institute of Masaryk Academy of Work in 1921 (Klímová, 1987; Kohoutek, 1998; Pech, 1937). The main mission of the Psychotechnic Institute was "research in human efficiency, psychic and physical, as a basis for selecting individuals for diverse vocations" (Průcha, 2019, p. 36), which created a significant link between guidance practised in the district centres and research studies (Kohoutek 1998; Pech 1937) and provided a basis for establishing the psychology of work as an independent field (Letovancová \& Lišková, 2009).

The situation in Slovakia was similar: the first guidance centre was established there in 1928 as a part of the Psychotechnics Institute of Bratislava. The Psychotechnics Institute in Bratislava continued to operate during WW II as a part of the Slovak State (1939-1945) and was made a part of the Institute of Human Work in 1947, a research institution for the psychology of work and partly also career guidance and counselling until its abolition in 1951.

The main purpose of these centres was to recommend a vocation or career choice to an individual and help them find a job and/or employ apprentices based on the results of comprehensive psychotechnics testing and, in some cases, also medical testing. It is interesting to note in this context that the staff of these centres mostly consisted of non-psychologists, often teachers trained in using individual techniques (Klímová, 1987; Kohoutek, 1998). Counselling work was dominated by individual (case-study) approach in line with the social philosophy of the time: "if the whole [authors: society] is to be apt, attention must be given to its members in the first place" (Stejskal, 1925, p. 295).

Besides these guidance centres in the districts, there were also other types of counselling centres such as those run by regional government centres for social care in secondary education, academic centres, army counselling centres, or psychotechnics counselling offices in big factories (Pech, 1937).

In addition to guidance centres in Bohemia, Moravia and partly also Silesia, there were public job recruitment offices. In Slovakia and Carpathian Ruthenia, the network of public job recruitment offices was only being built (Janák, 1998; Rákosník, 2008). Incorporation of job recruitment including vocational guidance services, i.e. institutionalising the link between job recruitment offices and guidance centres governed by the then Ministry of Social Care, however, did not happen during the so-called First Republic (1918-1938). However, according to the governmental decree of July 7, 1936, no. $217 \mathrm{Sb}$., at least one job recruitment 
office with an appropriate number of vocational guidance centres was to be set up in each district (Rákosník, 2008).

After World War II, the development of vocational guidance services in Czechslovakia was influenced by the fact that it was included in the zone occupied by the Union of the Soviet Socialist Republics (USSR), and from February 1948 the country was ruled by the Communist Party, slavishly copying policies of the Communist Party of the USSR. The principal problem of the early post-war years was the lack of a labour force and low work efficiency. The high demand for labour and the stipulations of Law no. 146/1946 Sb. that the state provide each of its citizens with a right to work and rightful remuneration (Kalinová, 2007) shifted the interpretation of the right to work (United Nations General Assembly, 1948) to an obligation of being employed which was required and monitored by the state.

Job recruitment was transformed into deployment of individuals in prioritised fields of the economy according to an economic plan (Kalinová, 2007). Deployment of apprentices and later graduates of all types of secondary schools and institutions of tertiary education became an administrative agenda entrusted to the governing bodies of the communist administration. The information activities necessary for an adequate choice of occupation turned into recruitment initiatives benefiting employers, especially those in heavy industry (Klímová, 1969; Kohoutek 1998). In fact, these steps, together with the closing down of most social welfare institutions including the Ministry of Work Protection and Social Care in 1951 (Kalinová, 2007), eliminated vocational guidance services.

The application of the Soviet model of society in 1948-1953 proved to be unsustainable for further development in Czechoslovakia at the political, economic as well as social levels. Specific changes which created space for a "comeback" of vocational guidance services started to be implemented only after the 20th Congress of the Communist Party of USSR in February 1956 (Kalinová, 2007; Klímová, 1969). From a professional perspective, the ratification of the Forced Labour Convention (ILO, 1930) in 1958 was just as important for restoring the system of vocational guidance as was the signing of Law no. 70 of 17 October 1958 (Národní, 1958), which made it compulsory for district people's committees to provide guidance services e.g. establishing psychological centres and psychological-educational clinics to handle, among other things, support for career choices.

The constitution of 1960 (Národní, 1960), which changed the federal structure of Czechoslovakia, and the adoption of the new Educational Act in 1960 (Klímová, 1987) created conditions for a search for new forms of guidance services in education. Within the new concept of "educational counselling", career choice was to be "an organic climax of a purposeful career education" (Bárta, 1962, p. 191) and, together with other counselling activities, was "to contribute to optimum development and socially productive use of all capacities and abilities in each individual and to become a part of a broad educational-psychological counselling" (Bárta, 1962, p. 191). When the new concept of educational counselling was being created, attention shifted to the worldwide trend embracing the educational model in psychological counselling (Drapela, 1971), combining career education with services of educational counsellors and/or psychologist-guidance educators. 
In 1960, experimental testing of career education was launched in schools, and after the experiment was evaluated as successful (Kohoutek, 1998), basic schools (up to 9th grade) and grammar schools started to introduce the post of educational counsellor (teacher) (Klímová, 1987). In Slovakia, from the end of the 1960s, experimental testing of the position of school psychologist was under way as an alternative to the "Prague concept of educational counselling", but these activities faded away after 1975 (Kopčanová, 2000; Štech \& Zapletalová, 2013).

Since 1967, career education was extended by services of regional specialised psychological centres, which diversified into district and regional pedagogical-psychological counselling centres in the early 1970s (Kohoutek, 1998). This created a basis for the provision of counselling services in the educational system, dominated by the topic of career choice, which, among other things, provided an argument for adopting ILO Convention no. 142 on professional orientation and vocational training for human resources development in 1975. The concept of educational counselling was fully authorised in 1984 (Klímová, 1987; Koščo et al., 1987).

The counsellors working in pedagogical-psychological counselling centres focused primarily on students requiring specific attention, which, in turn, necessitated comprehensive diagnostics (diagnostic for abilities, interests, and partly health status). In the long term, this process produced a significant group of psychologists acting as career counsellors, whose work was based on diagnostics.

The role of educational counsellors among teachers from all types of secondary schools and in special schools was to organise and provide information, to co-ordinate information activities with form teachers, and to provide methodological support to other teachers in the long-term professional orientation of students (MŠ ČSR 1980). A key part of implementing the concept of educational counselling was that teachers were responsible for career education (Maydlová, 1968), their task being "long-term observation of the development of the student's personality traits with focus on their future engagement with study or an occupation, and identifying and shaping individual interest in occupational choice" (Kohoutek, 1998, p. 43).

While in the period 1960-1992, the structure of services in educational counselling was uniform for all Czechoslovakia, there were some minor conceptual differences between the Czech and Slovak Republics (Kohoutek, 1998; Kopčanová, 2000) when comparing the Czech concept of educational counselling (represented by Marta Klímová) and the Slovak concept of educational-psychological counselling (represented by Jozef Koščo). The Czech concept of educational counselling stemmed from research by the Institute of Social Research of the Young and Educational Counselling of the Faculty of Education, Charles University and emerged in parallel with the development and current situation in other so-called capitalist and socialist countries. It emphasised career guidance as a part of child and youth education, with support for career development being one of the issues for attention. A key role was played by teachers and other pedagogical staff who were to influence all children and youth, and only in cases of difficulties, to proceed as indicated according to the results of comprehensive pedagogical-psychological diagnostics provided by pedagogical-psychological counselling centres (Klímová, 1974, 1987).

The Slovak concept of educational-psychological counselling which was based on the findings of the Research Institute of Child Psychology and Psychopathology 
in Bratislava and supported also by many psychologists based in Brno, emphasised the continuity of the psychic development of an individual to be supported in coping with developmental tasks by a system of psychological counselling institutions (Kohoutek, 1998). Thus the approach to issues of career selection by students was dominated by developmental psychology, grounded in the career development theory of Super (1957). Considering the comprehensive diagnostics provided by pedagogica-psychological counselling centres, this approach was intended to govern the follow-up pedagogical activities in schools as well (Koščo et al., 1987).

This architecture of guidance and counselling services, however, led to career choice being perceived as a matter of education provided jointly by the family and the school, and only in serious cases was the help of pedagogical-psychological counselling centres to be sought. It promoted the view among lay people that counselling services were only for those who "had a problem".

What proved to be a big drawback of this period in the long run was the connection between counselling practice and research. By its focus on research work, personality formation, and care for employees (Štech \& Zapletalová, 2013), the Czechoslovak Research Institute created an empirical basis for the psychology of work but not for career guidance. Research in career guidance practices was entrusted to regional pedagogical-psychological counselling centres (Kohoutek, 1998), which led to a chronic lack of experts able and willing to develop this field as a branch of counselling psychology in universities (Vendel, 2011).

Further development of vocational guidance services (in moving to career guidance services) was influenced not only by the fragmentation of the so-called "socialist block" but also by the split of Czechoslovakia. The change in the political life of Czechoslovakia after the so-called Velvet Revolution in November 1989 launched economic and social transformation, but after the election of 1992, in which advocates of reforms won in the Czech Republic, while opponents of reforms were more numerous in Slovakia, Czechoslovakia was heading for a split. Thanks to political negotiations, on January 1 1993, two new countries emerged in the heart of Europe, each of them following their own path, even in career guidance services.

\section{Post 1993 divergences}

In the Czech Republic, the economic transformation was based on principles of market economy and economic competition, minimising interference by the state, restoring private ownership and empowering development of services, but it led to slow economic growth (Machonin \& Tuček, 1996). The system of career guidance services had neither the opportunity nor the capacity to shape social transformation in a major way; its task was rather to eliminate the negative impact of social transformation on the lives of individuals.

The system of career guidance services within the governance of the Ministry of Education, Youth and Sports remained largely the same as under socialism, but the increasing diversity of issues that both parents and teachers were addressing through the individual units of the career guidance system, was pushing career choice issues into the background. The unemployment agenda was taken up by the Ministry of 
Labour and Social Affairs, namely by labour offices (Předsednictvo, 1990), providing information and counselling services under Employment Law no. 9/1990 Coll. (Česká, 1990). Newly established Information and Counselling Centres for the selection of a profession (IPSs), supported by the Phare programme from 1996 on, extended the remit of each labour office to career choice counselling for students of upper primary and secondary schools. This change in the activities provided by labour offices can be regarded as the point when two systems of career guidance and counselling started to develop alongside each other: the more dynamic system of employment public services under the governance of the Ministry of Labour and Social Affairs, and the system under the governance of the Ministry of Education, Youth and Sports, both taking up the tradition of educational counselling. Both ministerial spheres, whose goal was to direct the individual towards making the right decision (OECD, 2003), used similar procedures which reflected the nature of the qualifications of the then providers of these services. In both ministerial spheres, it was psychologists who guaranteed the professionalism of the services (Hloušková et al., 2004; OECD, 2003).

From the second half of the 1990s, economic, employment, and educational policies-all of them closely linked-were shaped by the national EU accession programmes. This, among other things, provided space for co-operation between the Ministry of Education and the Ministry of Labour regarding vocational guidance. One example of the connectedness of the individual policies, which contributed to career education counselling being innovated, was the compulsory inclusion of career education in the curricula of primary and secondary schools of all types (MŠMT, 2000, 2001). This measure was adopted by the Ministry of Education, Youth and Sports to increase the employment rate among school graduates who were adding to the unemployment rate in the Czech Republic at that time. However, co-operation between the two ministries lacked a clear conceptual framework of guidance provision. This significant change in co-operation between the ministries was brought about by the demands of the local socioeconomic context and not by legislative change concerning counselling services in the education system and employment offices after the EU accession of the Czech Republic (MŠMT, 2005; Parliament, 2004) nor by impulses from abroad steering the development of career guidance towards lifelong learning guidance (e.g. OECD, 2003, 2004a).

\section{Current situation: Czech Republic}

The current challenge for government is how to transform career guidance services under the governance of the Ministry of Education, Youth and Sports, and under the governance of the Ministry of Labour and Social Affairs into a lifelong learning guidance system.

The high degree of diversity within the educational system, arising from the high degree of decentralisation and autonomy of the system, is typical also of career guidance services provided in schools. Differences in student educational outcomes based on the socioeconomic status of students' families and also of attendance at different types of schools, as well as the increasing share of early leavers from 
education and training (age 18-24), which has risen from $5.4 \%$ in 2009 to $6.2 \%$ in 2018 (European Commission, 2019b), present its own challenges for innovations in career guidance outside schools.

The traditionally low cost of labour and therefore the cheap labour force in the Czech Republic has slowed the onset of robotisation and digitalisation, but as concerns synergies between adult labour force skills supply and growing robotisation and digitalisation, there is some hope in the growing tertiary educational attainment among people aged 30-34 (33.7\% in 2018) as well as the growing adult participation in learning with a rise from $7.1 \%$ in 2009 to $8.5 \%$ in 2018 (European Commission, 2019b). Since career guidance for employed adults has been neglected in the Czech Republic there are no reliable figures about the service provision for this segment of the population to improve

The labour market and the economy of Czech Republic is doing well in other respects. The employment rate had risen to 80.9\% by 2019 (European Commission, 2019a). Increasing the employment rates for women and older people (55-64) has been successful, as has increasing the employment rates among young people (15-24) and people with low qualifications (ISCED 0-2) (European Commission, 2019a). Also the share of young people in neither employment nor education and training (NEETs) has been decreasing-from $15.7 \%$ in 2009 to $12.5 \%$ in 2018 (Eurostat, 2020a). Non-profit organisations, which-again thanks to projects cofunded from the state budget - are providing career guidance services for the abovementioned (risk) groups in the labour market, have contributed significantly to this trend. Currently (before COVID crisis) the Czech Republic has the lowest unemployment rate (of 2-3\%) as well as the lowest number of applicants per job in the EU as well as among the OECD (European Commission, 2019a).

The account of the developments in the Czech Republic shows that the tradition of career guidance services established in the 1990s under the governance of two Ministries has persisted, despite generating an unclear profile of career guidance services, but this situation currently presents challenges to lifelong guidance policy development. The establishment of the National Guidance Forum, formalised in 2010, and having the status of an advisory body to the Ministry of Education, Youth and Sports and the Ministry of Labour and Social Affairs, has not to date produced a better solution than the status quo.

\section{Current situation: Slovakia}

Slovakia has the lowest rate of participation in adult learning in the CEE countries at $3.8 \%$ (Eurostat, 2020b). At the same time, the situation on the labour market reflects the neoliberal policies of successive governments based on privatisation, a flexible labour force, and low wages/low taxation. Slovakia scores very low on many Eurostat "quality of employment" indicators such as the rate of night work (highest in the EU) and the highest number of working hours in the EU. At the same time, the wage convergence with Western Europe is very slow (wages are $35 \%$ of the EU average). Slovakia also has one of the lowest unionisation rates in the EU (13\%). At the same time, low unemployment and shortages on the labour market only reinforce 
the vision of career guidance as a service that is primarily subordinate to the needs of the labour market.

Inequities in the educational system are rising, and the differences in educational outcomes between regions and social classes are some of the highest in the EU (European Commission, 2019c). The lack of inclusiveness in the educational system is especially visible in the case of the Roma population. To illustrate, the grade repetition rate is 15 times higher among pupils from socially disadvantaged environments and marginalised Roma communities compared to other pupils (Ministry of Finance of the Slovak Republic, 2020). The early school-leaving rate almost doubled between 2010 and 2018 (currently at 8.6\%) and is particularly high for pupils from marginalised Roma communities (37.2\%). The proportion of pupils with special educational needs is among the highest in Europe, and $5.9 \%$ of these pupils (EU: $1.6 \%$ ) are educated in special classes or special schools (European Commission, 2020). According to some estimates, around two thirds of Roma children attend a school where all or most other children are also Roma (FRA, 2016).

Career guidance in primary and secondary education is provided by educational counsellors at schools and by psychologists of the network of centres for pedagogical-psychological counselling and prevention (82 public and 12 private centres). Several European Social Fund co-funded projects realised between 2008 and 2016 have contributed to the development of guidance tools and methodologies and training materials for the staff responsible for guidance provision; however, they failed to sustainably increase the capacity of the system. The time allocation for educational and career counsellors at primary and secondary schools remains very low $(2-5 \mathrm{~h}$, depending on the size of the school). The cultural and methodological shift from psychological assessment is very slow at the pedagogical-psychological counselling and prevention centres. Career education is not present at school as a specific subject and is not sufficiently integrated into the curricula of other subjects (Grajcár \& Beková, 2012). In 2019 a new law on pedagogical staff was passed that introduced a new category of career counsellors and increased the number of hours for guidance provision. The development of the dual training system led in some cases to improved co-operation between schools and employers at the local and regional levels. An ongoing project funded through European Social Fund should develop standards for guidance within schools, increase capacities, and train regional coordinators for guidance in the educational sector (Ministry of Education, Science, Research and Sport of the Slovak Republic, 2019).

In higher education, since 2002, the Higher Education Act introduced an obligation for higher education institutions to provide information and counselling services, but in practice career centres are present at only a few higher education institutions, and their activities are often limited (Markovič, 2015). A system of tracking of graduates is under development.

In the sector of employment services, the launch of several ESF-funded (European Social Fund) projects in 2017-2019 aimed at providing career guidance for various vulnerable target groups (NEETs, long-term unemployed) has increased the availability of guidance for the unemployed. As of 2020, guidance services are provided by 300 counsellors in 46 regional labour offices. The services provided focus on career development skills based on an internal CMS framework, and PES 
also measure the distance travelled by the beneficiaries through an internal monitoring tool launched in 2018 (Šprlák, 2017). Career guidance is also available from external providers in the form of a skills audit/bilan de compétences for some of the registered jobseekers of the Slovak Public Employment Service (UPSVaR, 2018). Some type of career guidance was provided to 60,000 registered jobseekers in 2018, which represents around $33 \%$ of all registered jobseekers in that year.

Access to career guidance for working adults remains very limited. An ESFfunded project run from 2013 to 2015 established a network of regional guidance centres for adults. However, its narrow focus on orienting adults towards specific training courses has not led to an improvement in the availability of career guidance or in increased participation in lifelong learning. It has also highlighted the issue of sustainability in building and maintaining a new guidance infrastructure for adults. Career counselling for adults is available for working adults within PES, but only a few dozen citizens use it annually (UPSVaR, 2018). In recent years, the number of private career guidance providers has grown dynamically, but without public financial support, their services are affordable mainly to high-earning adults.

There is a growing consciousness among different stakeholders in Slovakia concerning the potential role of career guidance in surmounting these challenges, which is strongly reflected also in the intensification of activities in the civic sector, especially the Professional Association for Career Guidance and Career Development, responsible for the development of the national quality standard (Šprlák, 2020), organisation of the Careers Week, renewal of the National Guidance Forum, and the organisation of the annual IAEVG Conference in Bratislava in 2019.

\section{Historical overview: Hungary 1919-2010}

Between the two World Wars, Hungary established different guidance systems, neither of which were highly accessible to citizens in modern terms. The country, as successor state of the Austro-Hungarian monarchy, lost main territories and population when the Treaty of Trianon was signed in 1920. The modern boundaries of the country were settled. At the same time, new countries such as Czechoslovakia and the Kingdom of Serbs, Croats, and Slovenians (later Yugoslavia) were born.

Budapest was already a hub of modern psychological movement before the First World War. Sándor Ferenczi, Fülöp Stein, and Lipót Sondi were the key figures of the so-called Budapest psychological school under the strong influence of the works of Freud and Jung. Positive psychology, as it has been officially called since the 1980's, was also partially rooted in Budapest where Imre Herman and the medical doctor Michale Bálint started their professional careers. After collapse of the empire, Austrian and German connections remained important, but professional communication between Hungarians and other former nations of the empire became negligible. A short-lived Soviet Republic (the Republic of Councils) was established in Hungary for four months in 1919 which had, as one of its features, a unique allinclusive approach toward youth guidance.

By the late 1920s, in an economic sense, the country had recovered from the collapse of the empire. In 1929, the national social insurance set up a work capability 
screening unit. During the early years of the Second World War, the capital city of Budapest established a city psychological guidance centre. After the war and just before the communists took power, ten counties in the country established guidance centres.

Between 1947 and 1959, as part of the development of the planned communist economy, pedagogy, psychology, and guidance were forbidden. The 1956 uprising against the rigid and primitive Soviet system led to change. In 1959, the newly reestablished Ministry of Labour hosted a small unit for vocational psychology, led by János Csirszka. The Hungarian railways and the national post office also maintained small vocational laboratories. Csirszka's work supported the reinstallation of vocational psychology and career guidance in the country. In 1959 and 1961, the communist government approved two government resolutions on youth guidance as the violent industrialisation of the country in the 1950s took it sacrifices. The labour market was close to full employment, and a young labour force was firmly requested by state companies.

From the early 1970s until the mid-1980s, a new golden age of career guidance in Hungary arrived when the government set up a national youth career guidance institute and twenty county institutes to support the primary-secondary vocational education transitions through the country. This system was abolished in the 1980s when the transformation of the Hungarian economy towards a marked-based system had already started.

From 1988/89, the economic and political changes were clearly visible even for ordinary citizens as the macro-economic imbalance became a burning issue. After the political changes (1989/1990), the newly established public employment service became the key provider of career guidance services. In 1990, the new democratically elected parliament approved the establishment of the National Employment Agency. It mainly re-recruited most of the trained professionals, and applied a narrow approach in career guidance as mass unemployment was already an issue. Although most of the guidance professionals arrived with a career developmental approach to the new institution, the daily practice was about placement and a jobfirst approach. Also, the training of new career counsellors started from 1992 at the University of Gödöllo,, where a three-year-long college course was developed under a WB project in strong co-operation with Canadian and German guidance and research communities and which subsequently became the model for the Applied University of the Bundesagentur fur Arbeit in Mannheim (Borbély-Pecze, 2019). Guidance services under the social inclusion and education (school) sector remained disjointed with segmented professional capacities (Borbély-Pecze, 2018). The situation of the Hungarian Public Employment Service changed after 2010 as the new government had started to weaken the labour administration of the country.

\section{Current situation: Hungary}

There are two major policy drivers currently in Hungary: political and economic. Since 2010, Hungary has had the same ruling parties (FIDESZ-KDNP) in power, holding two-thirds of the parliamentary seats. The national economy and labour 
market went through a significant recovery period after the 2008-2009 crises, and the current GDP is higher than it was before the crisis. Moreover, Hungary has achieved a high employment rate (74.4\% in 2018 [EUROSTAT] for the 20-64 age group). These two facts, more or less, are enough for the average citizen to be safe or feel themselves safe economically. There is limited support for the further development of national career guidance services currently as the low unemployment rate and growing wages cause citizens to be satisfied with the situation. Most of the recent developments of the Hungarian guidance services have been concentrated on support for vulnerable groups or the early tracking of Hungarian youth towards blue-collar initial vocational education and to science, technology, engineering, and mathematics (STEM) occupations. The development of universal access or the support of the life-career transitions is not within the scope of the present policy design.

Despite the full recovery of the national labour market since the 2008 financial crisis, almost one third of the working-age population remains inactive, especially youth and older women (WB, 2019a). Unemployment benefit, providing financial support for jobseekers only for 3 months is the shortest in the EU. Unemployment has remained high in the eastern part of the country and internal labour mobility, due to the lack of a rental housing market, also remains low. A declining demographic - the working-age population fell by $7 \%$ between 2001 and 2017 -is the biggest vulnerability of the country, together with a no-migration/inclusion policy approach.

The European Commission highlighted the low educational outcomes for basic skills in Hungary based on PISA studies, especially for children from disadvantaged socio-economic backgrounds. Pupils are streamed early into different types of schools, with wide gaps in educational outcomes and employment paths. Poor health outcomes, aggravated by unhealthy lifestyles, persist in having a negative impact on human capital (European Commission, 2018).

A governmental focal point for the development of career guidance services and policy design has been missing for a long time. The work of the Hungarian National Lifelong Guidance Council was abolished in 2012. Since 2010, there has been no ministry for labour or ministry of education within the ministerial structures. The current ministries at the national level often cover wide portfolios, and only junior ministers, not members of the cabinet, are responsible for certain policies such as employment, youth, social inclusion, or education. It also means that there are no transparent available public data about the size and manpower or client-staff ratio of guidance services which remain segmented under different subsystems, such as outsourced NGO activities of the labour administration and in-house activities of the county pedagogical institutes. The latest survey concerning the number of professionals working in the field of career guidance was carried out in 2008 under the national lifelong guidance development programme (Borbély-Pecze, 2018).

After the recent general elections (2018), a new ministry for economy was established with the title of Ministry for Innovation and Technology (MoIT). Since 2019/2020 it has an extra-wide portfolio that integrates higher education, adult education, vocational education, and employment policies with innovation, state infrastructure developments, and maintenance. MoIT (Government of Hungary, 2019) issued a new strategy for initial vocational education in 2019 entitled "Vocational 
Education, Training and Adult Education 4.0". It dedicates one subchapter to career orientation but lacks a lifelong guidance perspective. One of the key actions of the national government is to support early tracking in grades 7 and 8 (final years) of primary school by offering the students and parents a reliable career orientation measurement/testing tool for initial vocational secondary education (grades 9-11/13). Career education as a concept has been mentioned several times since the change of the communist regime, but the concept is still far from the daily practice of most Hungarian schools. The current reality of the school career guidance is closest to orientation and programme-based individual actions such as a factory visit and career orientation fairs.

\section{Conclusions}

There is continuous and repeated debating, and interpretation and reinterpretation of history in CEE states where different nations have changed political systems every few decades in the 20th century.

\section{National identities}

From 1918, the end of World War I, until the fall of communism and entry into the EU (2004), Hungary, the Czech Republic, and Slovakia have experienced a huge number of social, political, and economic changes. Even state borders were not fixed until 1921. However, these countries represent a unique cultural geographical block, where country borders were sealed often during the $20^{\text {th }}$ century and history was reinterpreted at the nation-state level, even though communist ideology was a common element. The history and development of career guidance services and systems in CEE countries was not untouched by all of these changes. Mutual fresh and accurate knowledge about a neighbouring country's guidance system and services has remained at a low level, and still is. After the collapse of the Austro-Hungarian Empire in 1918/1921, Berlin and Paris were the reference points for guidance services development and deployment. Later, during the Cold War years, Moscow and the Soviet psychologists, such as Lev Vygotsky, and labour economists, such as Stanislav Gustavovich Strumilin, provided the references. Then, not surprisingly after the fall of the communist systems (1989/1991), CEE countries were more open to Western European, American, Canadian, and even Australian ideas and donors than to regional co-operation. These continuous political and institutional transitions still impact the conceptualisation, availability, quality, and usefulness of career guidance services and systems and, of course, the level of trust for any institutional structure in the national level.

\section{Weak polities}

CEE countries shared a common history under the empire, which later diverged in the 20th century. Due to the frequently changing political regimes, none of 
the career guidance-related institutional settings were long-standing. In the three decades since the collapse of the communist systems, the high level of unemployment was the first burning social issue; therefore, vocational guidance and employment counselling and placement was the answer. Then, the low efficiency and productivity of the labour force became the main policy focus. In recent times before the COVID-19 pandemic, a low productivity rate was prevalent; therefore, the low replacement rate of the pension-aged workforce became the main issue of policy design. Thus, there has been no time for the real development of career education in the region. The strong psychological origin keeps career guidance services in the role of diagnosing users, and this is still one of the strongest expectations of the different user groups as well as governments. This notion of career education remains partial, as users often see career guidance services as a single-use provision.

\section{Users' perspectives}

The users of career guidance services always bring their own histories to the guidance process. However, the development and maintenance of such services are always connected with economic-labour market and social-educational policies and never in isolation from these. The institutional settings of these services have their own history and mainly about guidance intervention, even if it is invisible or strongly in evidence as when the state coats of arms or the national flags are visible in the walls of the buildings. Therefore, understanding the historical and intergenerational context in which career guidance services have been established is highly relevant for the policy design, service development, and practice of career guidance.

\section{Strategic perspectives}

In the three countries, there are no national lifelong guidance strategies and the cooperation between the different sectors (mainly education and employment) is case by case. The lifelong and life-wide concept of career building is not reflected in the institutional settings. Most of the time, users come through a system rather than through professionals who in different institutional settings use cross-policy protocols to empower them. Career information provision is also segmented and based mainly on government sectoral needs; there are no single-entry points for citizens. National governments appear satisfied with the country and system evaluations that have been undertaken by the different European agencies, the OECD, or the WB. Criticism of the lack of inclusive, all-age career guidance systems is most often explicit but policy makers do not even recognise it as an action point. One of the biggest issues in the region is the level of trust between governments and citizens. As trust is always built on the historical past, the resilience of the career guidance services against governance alterations is so low that the users of guidance services often overlook these services through not recognising their existence. 


\section{Against splendid isolation}

Splendid isolation is a term used to describe the 19th-century British diplomatic practice of avoiding permanent alliances with other countries. As history has shown, particularly in a World War context, this practice has never had good political, social or economic outcomes for any single country.

The reinforcement of career guidance services and systems is implicitly and sometimes explicitly part of the dialogue or trialogue processes between international bodies (such as the ILO the World Bank Group (WB), OECD and individual countries. Within the EU, the European Semester process was launched with the Europe 2020 strategy in 2011, sometimes proposing action for the member states. It has been reinforced for the next decade as the part of the Europe 2020+ Strategy.

This article is a first step to building bridges with professionals in CEE countries, trying to end 100 year of local isolation mobilizing the outcomes of the two European Resolutions on lifelong guidance (EC, 2004, 2008) and the work of the European Lifelong Guidance Policy Network (2007-2015).

Supplementary Information The online version contains supplementary material available at https://doi. org/10.1007/s10775-021-09473-4.

\section{References}

Bárta, B. (1962). Analýza chyb v současných názorech na výchovně psychologické poradenství v ČSSR [Analysis of faults in contemporary opinions on educational psychological consulting centres]. In Sborník prací Filozofické fakulty brněnské univerzity. Řada filozofická, 11(B9), 191-202.

Barnes, S.-A., Bimrose, J., Brown, A., Kettunen, J., \& Vuorinen, R. (2020). Lifelong guidance policy and practice in the EU: trends, challenges and opportunities. European Commission Luxembourg. https://doi.org/10.2767/91185.

Berend, T. I. (1996). Central and Eastern Europe 1944-1993. Cambridge University Press. https:// doi.org/10.1017/CBO9780511581748.

Borbély-Pecze, T. B. (2018). The history of the Hungarian Public Employment Service in narratives 1991-2006. Ministry for National Economy Finance. https://nfsz.munka.hu/Lapok/a_szolgalat_ konyv.aspx

Borbély-Pecze, T. B. (2019). From career decision-making towards career cruising: The case of Hungary, the "U" model Journal for Perspectives of Economic Political and Social Integration. Journal for Mental Changes, 25(2), 7-23. https://doi.org/10.18290/pepsi-2019-0006.

CEDEFOP. (2019a). European centre for the development of vocational training investing in career guidance. https://www.cedefop.europa.eu/files/2227_en.pdf

CEDEFOP. (2019b). CareersNet. Cedefop's network for lifelong guidance and career development. https://www.cedefop.europa.eu/en/events-and-projects/networks/careersnet

Česká národní rada. (1990). Zákon č. 9/1990 Sb., ze dne 19. prosince 1990 o o zaměstnanosti a působnosti orgánů České republiky na úseku zaměstnanosti [Law no. 9/1990 Coll., of 19 December 1990 on employment and the competence of the bodies of the Czech Republic in the field of employment].

Cipolla, Carlo M. (1973). The emergence of industrial societies-1. Fontana Economic History of Europe. pp. 228-278. Collins.

Commission of the European Communities. (2001). Making a European Area of Lifelong Learning a reality. https://www.europarl.europa.eu/meetdocs/committees/cult/20020122/com(2001)678_en.pdf 
Concering the Hungarian Parliament. (1884). Ipartörvény (Industrial Act, 1884. XVII.). https://net.jogtar.hu/getpdf?docid=88400017.TV\&targetdate $=\&$ printTitle $=1884 .+\% \mathrm{C} 3 \%$ A9vi + XVII.+t $\%$ C3\% B6rv\%C3\%A9nycikk\&referer=1000ev.

Council of the European Union. (2004). Draft Resolution of the Council and of the representatives of the Member States meeting within the Council on Strengthening Policies, Systems and Practices in the field of Guidance throughout life in Europe. https://www.cedefop.europa.eu/files/954-att1-1-Counc il_Resolution_on_Guidance_280504-EN.pdf

Council of the European Union. (2008). Council Resolution on better integrating lifelong guidance into lifelong learning strategies https://www.consilium.europa.eu/ueDocs/cms_Data/docs/pressData/en/ educ/104236.pdf

Directorate General for Employment, Social Affairs and Inclusion. (2011). The network of European public employment services: PES strategy 2020 and beyond. https://www.pesnetwork.eu/download/pesnetwork-strategy-2020-and-beyond/

Drapela, V. J. (1971). Marxist guidance: A dialectic lesson. Journal of Counseling \& Development, 49(5), 361-369. https://doi.org/10.1002/j.2164-4918.1975.tb04096.x.

ELGPN: European Lifelong Guidance Policy Network. (2012). Tools no. 1. Lifelong guidance policy development: A European resource kit. http://www.elgpn.eu/publications/browse-by-language/engli sh/ELGPN_resource_kit_2011-12_web.pdf/

ELGPN: European Lifelong Guidance Policy Network. (2015). Guidelines for policies and systems development for lifelong guidance: A reference framework for the EU and for the Commission. http:// www.elgpn.eu/publications/browse-by-language/english/elgpn-tools-no-6-guidelines-for-policiesand-systems-development-for-lifelong-guidance/

ETF European Training Foundation. (2003) Review of career guidance policies in 11 accessing and candidate countries-Synthesis report. https://www.etf.europa.eu/en/publications-and-resources/publi cations/review-career-guidance-policies-11-acceding-and-candidate

European Commission. (2018). Recommendations for council recommendations on the national reform plan of Hungary 2018 and delivering a council opinion on the 2018 convergence programme of Hungary. COM (2018) 416 final 23.05.2018.

European Commission. (2019a). Country report Czech Republic 2019 European semester: Assessment of progress on structural reforms, prevention and correction of macroeconomic imbalances, and results of in-depth reviews under Regulation (EU) No 1176/2011. https://eur-lex.europa.eu/legalcontent/EN/TXT/PDF/?uri=CELEX:52019SC1002\&from $=\mathrm{CS}$

European Commission European Union. (2019). Education and training monitor 2019-Czech Republic. Publications Office of the European Union. https://doi.org/10.2766/908631.

European Commission European Union. (2019). Education and training monitor 2019-Slovakia. Publications Office of the European Union. https://doi.org/10.2766/90532.

European Commission. (2020). Country report Slovakia 2020 European semester: Assessment of progress on structural reforms, prevention and correction of macroeconomic imbalances, and results of in-depth reviews under Regulation (EU) No 1176/2011. https://eur-lex.europa.eu/legal-content/EN/ TXT/?qid=1584543810241\&uri=CELEX\%3A52020SC0524

European Committee of the Regions. (2018). Addressing brain drain: A local and regional dimension. Luxembourg. https://doi.org/10.2863/250544. https://cor.europa.eu/en/engage/studies/Documents/ addressing-brain-drain/addressing-brain-drain.pdf

Eurostat. (2020a). Young people neither in employment nor in education and training by sex, age and labour status (NEET rates). https://appsso.eurostat.ec.europa.eu/nui/show.do?dataset=edat_lfse_ 20\&lang=en

Eurostat. (2020b). Adult participation in learning by sex. http://appsso.eurostat.ec.europa.eu/nui/show. do?lang=en\&dataset=sdg_04_60

FRA-European Union Agency for Fundamental Rights. (2016). Fundamental rights report 2016. https:// doi.org/10.2811/48916 (online version). https://fra.europa.eu/sites/default/files/fra_uploads/fra2016-fundamentalrights-report-2016-2_en.pdf

Gebauer, F. (Ed.). (2017). Changes - elections. 50 years of the Budapest Guidance Centre (Változások -Választások. 50 éves a fóvárosi pályaválasztási tanácsadó). Budapest Pedagogy Institute. https:// palyavalasztas.fpsz.hu/tortenet/

Government of Hungary. (2019). VET 4.0" Strategy for the renewal of vocational and adult education under the fourth industrial revolution (1168/2019. (III. 28). Government edict). https://net.jogtar.hu/ jogszabaly?docid=A19H1168.KOR\&txtreferer $=00000001 . t x t$ 
Grajcár, Š, \& Beková, L. (2012). Zručnosti pre riadenie vlastnej vzdelávacej a profesijnej dráhy a ich rozvoj $v$ sektore vzdelávania [Career management skills and their development in the educational sector]. SAAIC.

Hlavačka, M., Cibulka, P., Bek, P., Fejtová, O., \& Pokorný, J. (2015). Sociální myšlení a sociální praxe $v$ českých zemích 1781-1939 [Social thinking and social practice in the Czech lands 1781-1939]. Historický ústav AV ČR.

Hloušková, L., Knotová, D., Novotný, P., Pol, M., Rabušicová, M. (2004). Vzdělávání poradců v České republice [Education and training of counsellors in the Czech Republic].

ILO_International Labour Organisation. (1930). Convention number 29-Forced labour convention. https://www.un.org/ruleoflaw/files/ILO_Convention_29.pdf

ILO-International Labour Organisation. (1975). Convention number 142-International human resources development convention. https://www.ilo.org/dyn/normlex/en/f?p=NORMLEXPUB: 12100:0::NO::P12100_INSTRUMENT_ID:312287

ILO-International Labour Organisation. (2015). Employment protection legislation: Summary indicators in the area of terminating regular contracts (individual dismissals). https://www.ilo.org/ travail/areasofwork/WCMS_357390/lang--en/index.htm

Inglehart, R. \& Welzel, C. (2015). The WVS Cultural Map of the World. http://www.worldvaluessurv ey.org/wvs/articles/folder_published/article_base_54

Janák, J. (1997). Snahy o zavedení veřejnoprávního zprostředkování práce na Moravě a ve Slezsku před rokem 1918 [Efforts for introducing public job recruitment in Moravia and Silesia before 1989]. In Sborník prací Filosofické fakulty brněnské university (pp. 95-116). Řada historická, 46(C44), 95-116.

Janák, J. (1998). Osnova zákona o zprostředkování práce z let 1919-1922 [Entwurf des Arbeitsvermittlungsgesetzes in den Jahren 1919-1921]. In Sborník prací Filozofické fakulty brněnské univerzity (pp. 133-155). Řada historická, 47(C45), 133-155.

Kalinová, L. (2007). Společenské proměny v čase socialistického experimentu. K sociálním dějinám v letech 1945-1969 [Social change in times of a socialist experiment]. Academia.

Klímová, M. (1969). Školní a profesionální poradenství [School and vocational guidance]. Ministerstvo pro mládež a tělesnou výchovu ČSR.

Klímová, M. (1974). Výchovné poradenství v ČSSR a obdobné poradenské systémy v zahraničí [Educational counselling in the Czech Socialist Republic and similar counselling systems abroad]. Ústav školských informací při Ministerstvu školství ČSR.

Klímová, M. (1987). Teorie a praxe výchovného poradenství [Theory and practice of educational counselling]. SPN.

Kohoutek, R. (1998). Historie pedagogicko-psychologického poradenství [History of pedagogicalpsychological counselling]. Pedagogická orientace, 8(3), 30-45.

Kopčanová, D. (2000). Educational and psychological counselling in Slovakia: Keeping continuity. International Journal for the Advancement of Counselling, 52, 209-223. https://doi.org/10. 1023/A:1005581606554.

Koščo, J., Fabián, D., Hargašová, Hlavenka, V., Rapoš, I., Hrabal, V. (1987). Poradenská psychológia [Vocational psychology]. Slovenské pedagogické nakladatel'stvo.

Lancová, J. (1925). Poradny pro volbu povolání [Counselling centres for vocational guidance]. In J. Lancová, O. Říha, C. Stejskal, \& F. Šeracký, Správná volba povolání [Good occupational choice] (pp. 299-348). Ústředí poraden pro volbu povolání.

Letovancová, E., \& Lišková, E. (2009). Psychologie práce a organizace [Psychology of work and organization]. In B. Baštecká (Ed.), Psychologická encyklopedie. Aplikovaná psychologie [Psychological encyclopedia. Applied psychology] (pp. 272-277). Portál.

Machonin, P. \& Tuček, M. (Eds.). (1996). Česká společnost v transformaci. K proměnám sociální struktury. [Czech society in transition. Towards changes in social structure]. Sociologické nakladatelství SLON.

Markovič, D. (2015). Kariérové poradenstvo v prostredí vysokých škôl na Slovensku [Career guidance at Slovak universities]. Verbum.

Maydlová, Z. (1968). Poznámky k metodám individuálního sledování a hodnocení žáků při výchově k povolání a jeho volbě [Notes on methods of individual monitoring and evaluation of pupils in career education and decision-making]. Výchovný poradce, 5(1), 39-51.

Ministry of Education, Science, Research and Sport of the Slovak Republic. (2019). Vyzvanie OPLZPO1/2019/NP/1.1.1-04 pre národný projekt s názvom Štandardizáciou systému poradenstva a prevencie $k$ inklúzii a úspešnosti na trhu práce. [Call OPLZ-PO1/2019/NP/1.1.1-04 for the 
national project Standardization of the Counselling and Prevention System for Inclusion and Success on the Labour Market]. https://www.minedu.sk/25042019-vyzvanie-oplz-po12019np1 11-04-pre-narodny-projekt-s-nazvom-standardizaciou-systemu-poradenstva-a-prevencie-k-inklu zii-a-uspesnosti-na-trhu-prace/

Ministry of Finance of the Slovak Republic. (2020). Revízia výdavkov na skupiny ohrozené chudobou alebo sociálnym vylúčením [Spending review on groups at risk of poverty or social exclusion]. https://www.minedu.sk/data/att/15944.pdf

MŠ ČSR. (1980). Vyhláška Ministerstva školství České socialistické republiky č. 130/1980 Sb., ze dne 28. srpna 1980 o výchovném poradenství [Decree of the Ministry of Education of the Czech Socialist Republic no. 130/1980 Coll., of 28 August 1980, on educational counselling]. In Sbírka zákonů Československá socialistická republika. http://ftp.aspi.cz/opispdf/1980/031-1980.pdf

MŠMT. (2000). Metodický pokyn k zařazení učiva Úvodu do světa práce do vzdělávacích programů středních škol. Čj. 22067/2000-2 [Methodological instruction to include issues on Introduction to world of work into the secondary schools' curricula. Ref. No. 22067/2000-2].

MŠMT. (2001). Metodický pokyn k zařazení vzdělávací oblasti Výchova k volbě povolání do vzdělávacích programů pro základní vzdělávání. Čj. 19485/2001-22 [Methodological instruction to include the area of education, Education for choosing a profession, into the primary schools' curricula. Ref. No. 19485/2001-22].

MŠMT. (2005). Vyhláška č. 72/2005 Sb., o poskytování poradenských služeb ve školách a školských poradenských zařízeních ze dne 9. února 2005 [Decree no. 72/2005 Coll., of 9 February 2005, on the provision of counseling services in schools and school counseling facilities]. In Sbírka zákonů Česká republika ročník 2005, částka 20, rozeslána dne 17. února 2005, s. 490-502.

Národní shromáždění Republiky československé. (1958). Zákon č. 70/1958 Sb., ze dne 17. ř́ijna 1958 o úkolech podniků a národních výborů na úseku péče o pracovní síly [Law no. 70/1958 Coll., of 17 October 1958 on the tasks of undertakings and district people's committees in the field of labour care]. https://www.zakonyprolidi.cz/cs/1958-70

Národní shromáždění Republiky československé. (1960). Ústavní zákon č. 100/1960 Sb., ze dne 11. července 1960, Ústava Československé socialistické republiky [Constitutional law no. 100/1960 Coll., of 11 July 1960, Constitution of the Czechoslovak Socialist Republic]. https://www.psp.cz/ docs/texts/constitution_1960.html

OECD: Organisation for Economic Co-operation and Development. (2003). Policies for information, guidance and counselling services. National questionnaire Czech Republic. http://www.oecd.org/ education/innovation-education/2500586.pdf

OECD: Organisation for Economic Co-operation and Development. (2004a). Career guidance. A handbook for policy makers. http://www.oecd.org/education/innovation-education/34060761.pdf

OECD: Organisation for Economic Co-operation and Development. (2004b). Career guidance and public policy- bridging the gap. http://www.oecd.org/education/innovation-education/34050171.pdf

OECD: Organisation for Economic Co-operation and Development. (2019). Skills Strategy-Skills to shape a better future. https://doi.org/10.1787/9789264313835-en. http://www.oecd.org/skills/oecdskills-strategy-2019-9789264313835-en.htm

Parlament České republiky. (2004). Zákon č. 435/2004 Sb., ze dne 13. května 2004 o zaměstnanosti [Law no. 435/2004 Coll., of 13 May 2004 on employment]. https://www.zakonyprolidi.cz/cs/2004-435

Pech, O. (1937). Př́ruční slovník pedagogický [Pedagogical Dictionary]. Nákladem Česko-slovenské grafické Unie a. s.

Předsednictvo České národní rady. (1990). Zákonné opatření předsednictva České národní rady o zř́zení úřadi práce. Opatření č. 306/1990 Sb. [Legal provision of the presidium of the Czech National Assembly on establishment of employment offices. Provision no. 306/1990 Call]. https://www. zakonyprolidi.cz/cs/1990-306

Průcha, J. (2019). Odborné školství a odborné vzdělávání. Fungování systému, problémy praxe a výzkum [Vocational education and training. System functioning, practice problems and research]. Wolters Kluwer.

Rákosník, J. (2008). Odvrácená tvář meziválečné prosperity. Nezaměstnanost v Československu v letech 1918-1938 [An adverse face of inter-war prosperity. Unemployment in Czechoslovakia in 19181838]. Karolinum.

Šprlák, T. (2017). Zisłovanie výsledkov poradenských služieb na úradoch práce, sociálnych vecí a rodiny [Measuring the results of guidance services in Slovak labour offices]. Kariérové poradenstvo v teórii a praxi, 6(12), 31-37. https://www.euroguidance.sk/document/casopis/12.pdf 
Šprlák, T. (2020). Slovenské kariérové poradenstvo: dozrievame ku kvalite? [Career guidance in Slovakia: Maturing towards quality?]. Kariérové poradenstvo v teórii a praxi, 7(14), 6-29. https://www. euroguidance.sk/document/casopis/14/02_KPJ_2-2018_Sprlak.pdf

Štech, S., \& Zapletalová, J. (2013). Úvod do školní psychologie [Introduction to school psychology]. Portál.

Stejskal, C. (1925). O poslání poraden pro volbu povolání. [On the mission of counselling centres for vocational guidance]. In J. Lancová, O. Říha, C. Stejskal, \& F. Šeracký. Správná volba povolání [Good occupational choice] (pp. 289-295). Ústředí poraden pro volbu povolání.

Super, D. E. (1957). The Psychology of Careers. Harper \& Row.

Szúcs, J., \& Parti, J. (1983). The three historical regions of Europe: An outline. Acta Historica Academiae Scientiarum Hungaricae, 29(2/4), 131-184.

United Nations General Assembly. (1948). Resolution 217 (III) A. The universal declaration of human rights. https://www.un.org/en/ga/search/view_doc.asp?symbol=A/RES/217(III)

United Nations-Helliwell F. J., Layard, R., Sachs, D. J. ,\& De Neve, J. E. (Eds.). (2020). World Happiness Report. https://happiness-report.s3.amazonaws.com/2020/WHR20.pdf

UPSVaR. (2018). Vyhodnotenie uplatňovania aktívnych opatrení na trhu práce za rok 2018 [Evaluation of the active labour market policies 2018]. https://www.upsvr.gov.sk/buxus/docs/statistic/aotp_ 2018/Vyhodnotenie_AOTP_2018.pdf

Vendel, Š. (2011). Kariérové poradenstvo: súčasný stav a perspektivy [Career counseling: Current status and perspectives]. Československá psychologie, 55(6), 499-509.

Watts, A. G., \& Borbély-Pecze, T. B. (2011). The development of a lifelong guidance system in Hungary. International Journal for Educational and Vocational Guidance, 11(1), 17-28. https://doi.org/10. 1007/s10775-010-9187-7.

Watts, A. G., Sultana, R., \& McCarthy, J. (2010). The involvement of the European Union in career guidance policy: A brief history. International Journal for Educational and Vocational Guidance, 10, 89-107. https://doi.org/10.1007/s10775-010-9177-9.

WB: World Bank Group. (2019a). People, portraits, perspectives: Improving employability for inclusive growth in Hungary. http://documents.worldbank.org/curated/en/378951560973594851/People-Portr aits-Perspectives-Improving-Employability-for-Inclusive-Growth-in-Hungary

WB: World Bank Group. (2019b). Migration and remittances data: Annual remittances data (updated as of Oct. 2019). https://www.worldbank.org/en/topic/migrationremittancesdiasporaissues/brief/migra tion-remittances-data

Publisher's Note Springer Nature remains neutral with regard to jurisdictional claims in published maps and institutional affiliations. 